\title{
PÓSTER 19
}

\section{REGISTRO ELECTROMIOGRÁFICO DE LA DEGLUCIÓN EN NIÑOS DE 6 A 8 AÑOS CON FRENILLO LINGUAL NORMAL Y ALTERADO}

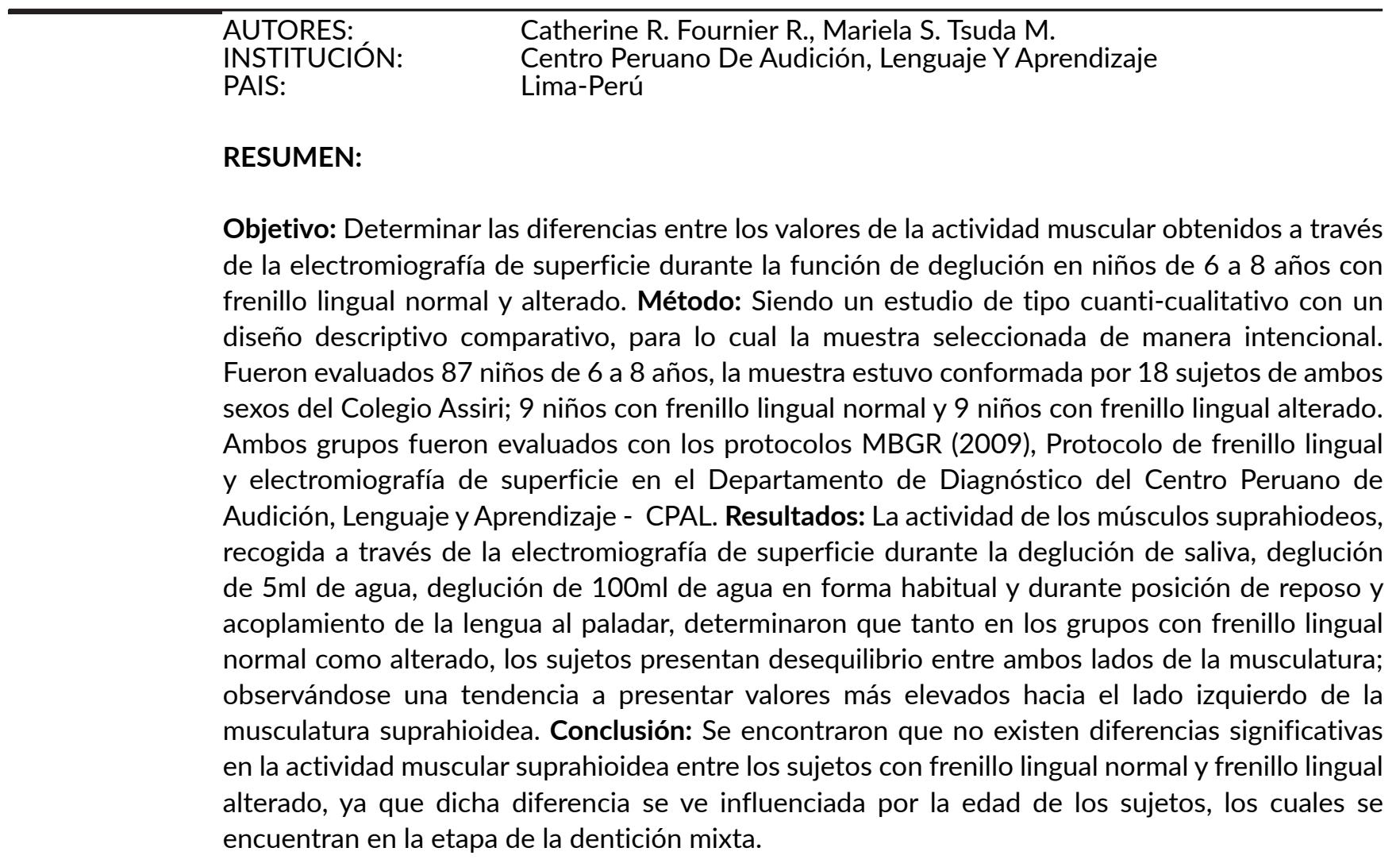

Palabras clave: Electromiografía de superficie, Frenillo lingual normal, Frenillo lingual alterado, Deglución

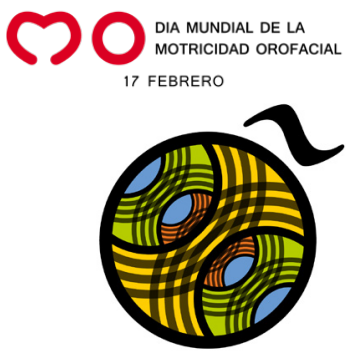

